\title{
Strategic Responses During Frugal Innovation at the Base of the Pyramid: the Case of Philips Community Life Centres
}

\author{
Elsie Onsongo ( $\nabla$ eonsongo@cfia.network) \\ Centre for Frugal Innovation in Africa - Kenya Hub Ring Road Westlands Lane
}

\section{Research}

Keywords: frugal innovation, base of the pyramid, organisational strategy

Posted Date: December 14th, 2021

DOI: https://doi.org/10.21203/rs.3.rs-1067187/v1

License: (9) (7) This work is licensed under a Creative Commons Attribution 4.0 International License. Read Full License 


\section{Abstract}

When multinational enterprises (MNEs) seek to serve the needs of base of the pyramid (BOP) environments, they are often confronted with several environmental factors, among them, severe resource constraints and institutional complexities. MNEs adopt two overarching strategic orientations to navigate these factors: the strategy to adapt to the new context, or the strategy to shape the context. This paper investigates how and when these strategic orientations are deployed in an MNE. It further explores the intra-organisational tensions and dilemmas that arise when these strategic orientations are implemented. This paper analyzes a case of frugal innovation in a primary care intervention developed and deployed in Kenya by Philips N. V., a Dutch multinational technology company. Several propositions are generated based on the case findings. The paper contributes to the frugal innovation literature which lacks rigorous, in-depth analytical case studies on organisational processes associated with new product development. It also offers managers a useful toolkit that could inform how they could strategically navigate the pressures of BOP environments.

\section{Introduction}

As markets in industrialized economics are becoming more saturated, multinational enterprises are now turning to emerging markets to sustain growth and profitability (Ernst et al. 2015; Luo 2003; London, Anupindi, and Sheth 2010). These multinationals, which are used to serving relatively high-income markets, must be innovative in order to enter relatively low-income successfully and resource-constrained environments, often considered to be highly uncertain (Khanna and Palepu 1997; Schuster and Holtbrügge 2014). A growing but varied body of literature pioneered by Prahalad and Hammond (2002) has focused on 'base of the pyramid' (BOP) markets and the efforts to serve them through innovative products and business models (see Kolk, Rivera-Santos, and Rufín 2014; Hart, Sharma, and Halme 2016; Dembek and Sivasubramaniam 2016 for reviews). This paper focuses on frugal innovation-a relatively new stream of research that attempts to conceptualize the innovative efforts of enterprises and other actors to address the needs of BOP markets (Agarwal et al. 2017; Cunha et al. 2014; Leliveld and Knorringa 2018; Pisoni, Michelin, and Martignoni 2018; Bhatti 2012).

Research on frugal innovation and entrepreneurship in base of the pyramid (BOP) contexts has so far considered how technologies and business models are redesigned to fit with resource-constrained environments, with a focus on affordability (Cunha et al. 2014; Leliveld and Knorringa 2018; Liu and Wei 2018). Along with the BOP literature in general, the frugal innovation literature acknowledges that BOP environments have unique characteristics; they are resourceconstrained and institutionally complex, and these characteristics are seen both as a challenge and as an opportunity for innovation (Onsongo 2017; Agarwal and Brem 2012; Sharma and lyer 2012). Several conceptual studies highlight two overarching strategic orientations when multinationals enter or operate in BOP markets: the strategy to adapt to the new context, or the strategy to shape the context (Ausrød, Sinha, and Widding 2017; Khanna, Palepu, and Sinha 2005). The choice between using the strategy to adapt or to shape the market is often presented as a dilemma in the literature: a business that adapts to the context faces the risk of not being innovative enough to be competitive, while a business that attempts to shape the context deliberately may risk losing legitimacy (Scherer, Palazzo, and Seidl 2013; Ausrød, Sinha, and Widding 2017). However, existing studies have yet to investigate these dynamics empirically in the context of frugal innovation. Further, an empirical analysis of how these strategies affect the internal operations of the multinational are lacking.

Therefore, the research questions investigated in this study are as follows: How does a multinational enterprise entering the BOP deploy strategic orientations to either adapt to or shape the new context? What are the intra-organisational consequences of deploying these strategies at the BOP? To address these questions, the paper analyses a case study of frugal innovation in healthcare in Kenya, in particular, Philips Community Life Centres (CLC) developed and deployed by Philips N. V., a Dutch multinational technology company. A CLC is a platform that bundles new technologies and integrated service offerings into primary healthcare. It upgrades and transforms primary healthcare facilities in semi-urban, rural and remote areas into social and economic community hubs, with community engagement at the core of product development and facility management. The case is analysed based on Khanna and Palepu's (2005) Five Contexts framework that can be used to map the contextual terrain of any operating environment in a country.

The rest of the paper is organized into four sections. The next section provides the theoretical context, followed by a brief description of the empirical setting and the research methodology. Subsequently, the paper presents the findings of the analysis of the case, the discussion. The final section raises the implications both for theory and practice, the limitations of the study, and an outlook for future research.

\section{Theoretical Framework}

\section{Frugal Innovation}

Frugal innovation as a concept has recently gained increased attention from scholars and practitioners alike. This is because resource scarcity is now a feature of not only BOP markets-where the frugal innovation discourse initially focused on-but also wealthier industrialized markets (Cunha et al. 2014, Kroll and Gabriel 2020, von Zedtwitz et al. 2015). Thus, organizations must figure out how to effectively serve their markets with affordable products and services while minimizing waste in the whole value chain.

There are various definitions of frugal innovation in the literature, each highlighting different elements such as the philosophy, the product, the underlying innovation process, the outcome, the target market or region, and other criteria. The consensus is forming around the following defining aspects: frugality as a philosophy, mindset or paradigm for both producers and consumers (Onsongo and Knorringa 2020, Brem and Wolfram 2014, Soni and Krishnan 2014), high quality and easy-to-use products and services developed with minimal resources (Tiwari and Herstatt 2012, Ramdorai and Herstatt 2015, Sehgal, Dehoff, and Panneer 2010), and the disruptive nature of frugal products in new markets (Rao 2013, Zeschky, Winterhalter, and Gassmann 2014). Where the target market is the BOP, frugal products and services should be affordable and accessible (Liu and Wei 2018, Leliveld and Knorringa 2018). These features are also attractive to wealthier customer segments that embrace frugality for reasons such as voluntary simplicity and environmental sustainability (Winkler et al. 2019, Kroll and Gabriel 2020), or lower disposable incomes due to economic crises (Bound and Thornton 2012, Cunha et al. 2014). 
This study focuses on frugal innovation in the BOP.

\section{The nature of BOP contexts}

Following the lead of Prahalad and Hammond (2002) who coined the term, BOP contexts have been defined based on per capita income at or below US\$1,500 or US\$2,000 per annum. The BOP market has also been described based on the household poverty threshold of US\$1 or US\$2 per day (Banerjee and Duflo 2007). BOP markets were previously associated with entire countries and regions in Africa, Asia and Latin America (Kolk, Rivera-Santos, and Rufín 2014), or even more generally, emerging markets (Khanna, Palepu, and Sinha 2005). The discourse has, however, evolved to focus on customer segments characterized by strong resource constraints and poor market access-a perspective that this paper adopts.

Along with poverty as the foundational factor of the BOP, these contexts are characterized by resource constraints and institutional complexities. From a foreign entrant's perspective, resource constraints in BOP contexts relate factors of production, i.e. shortages of high-quality raw materials and commodities, inadequate infrastructure such as power supply, water, roads and logistics, and deficiencies of specific business or technical skills in the human resources available (Mair and Marti 2009, Khanna, Palepu, and Sinha 2005, Ernst et al. 2015). Further, BOP contexts are exemplified by 'institutional voids', i.e. deficiencies or absences of formal market institutions such as capital markets, governance mechanisms, and property rights protections that make doing business challenging (Khanna and Palepu 1997, Mair and Marti 2009). An alternative view highlights' institutional complexity', i.e. the coexistence of formal market and political institutions, and informal traditional or indigenous political, social and cultural institutions that result in an uncertain and ambiguous environment (Mair, Marti, and Ventresca 2012, Onsongo 2017).

The challenge for an MNE entering these settings therefore involves effectively navigating and leveraging these complexities. We next explore the strategies that organizations that engage in frugal innovation employ to succeed in BOP environments.

\section{Strategic choices in BOP contexts}

Strategic choices for MNEs in BOP contexts-including those engaging in frugal innovation-essentially focus on whether (1) to adapt to local conditions, or (2) to alter those local conditions in order to maintain their usual mode of operations so as to leverage their global competitive resources (Khanna, Palepu, and Sinha 2005, Peng 2003, Ausrød, Sinha, and Widding 2017). In fitting with the first alternative of 'going local', frugal innovation has been conceptualized as a process of adapting technologies and related business models to the constraints of BOP contexts. The adaptation process on one hand involves reengineering products and business models to fit the context and address the needs of consumers (Zeschky, Widenmayer, and Gassmann 2011), and on the other hand, innovating or experimenting with the business models that deploy those technologies (Chesbrough 2010, George, McGahan, and Prabhu 2012). Therefore, efforts to adapt to context are driven by the external environment.

The large body of work in entrepreneurship and neo-institutionalism has shown however that entrepreneurs do not just blindly respond to what exists in their environment, entrepreneurs engage in purposive actions and practices aimed at change (Bruton, Ahlstrom, and Li 2010). Pioneering entrepreneurs in nascent markets are incentivized to change the institutional environment in ways that reinforce their interests (Battilana, Leca, and Boxenbaum 2009), and reduce environmental complexity by imposing familiar routines and standards (Boisot and Child 1999). Thus, the second alternative focused on altering local conditions may involve changing institutional environments to facilitate the deployment of new (frugal) products or services.

In sum, organisations are unlikely to be invariably passive or active, conforming or resistant, or adapting to the context or shaping the context. Rather, as Oliver (1997) argues, their behaviour is predictable based on the nature of the local conditions.

\section{Intra-organisational consequences of BOP strategic choices}

In deploying either or both of these strategic choices, foreign entrants confront conflicting pressures. On one hand, they want to align with their global norms to leverage their competitive clout, and on the other hand, also align with local norms in favour of creating a better fit with the local institutional environment (Peng 2003). These pressures are exacerbated for MNEs that are non-monolithic, and those that face conflicting sets of external environments. Additionally, MNEs may also have complex internal environments with inconsistencies and conflict among the interests, values, practices, and routines used in the various parts of the organization (Kostova et al., 2008). Therefore, we expect to see various tensions within the organization as it deploys either of these strategies.

Adaptation to the context from the perspective of frugal innovation involves changing existing organizational designs to accommodate low-cost innovation, and reconfiguring how value is created and captured to gain access to and compete in BOP settings (George, McGahan, and Prabhu 2012). A frugal mindset needs to be adopted, and this may manifest through bricolage (Baker and Nelson 2005), effectuation (Sarasvathy 2001), and improvisation (Radjou, Prabhu, and Ahuja 2012). These processes are associated mainly with local enterprises innovating under resource constraints. For an MNE to embrace this logic, it may entail shifting the entire internal logic of the organization and learning from the practices of successful local entrepreneurs that operate from de facto frugal mindsets. In a practical sense, adopting a frugal attitude may involve focusing on 'good enough' solutions, which implies a constant evaluation of the ideal balance between quality, cost and functionality in response to local requirements and constraints. In general, shifting internal organization logics has proven to be a challenging task due to cognitive biases entrenched by operating successfully in markets that are fundamentally different from the BOP. Consequences of the choice to shape the context through frugal innovation may be a short-term loss of competitiveness as the organisation builds legitimacy for its new products.

The following section investigates the rationale underlying various strategic choices made by the Western MNE Philips N.V. as it deployed healthcare facilities in Kenya, and subsequently explore the resulting intra-organisational tensions.

\section{Methodology}




\section{The Empirical Context and Case Study}

Koninklijke Philips N.V. is a multinational technology company headquartered in Amsterdam, The Netherlands, with operations in Europe, Asia, North and South America, Oceania and most recently, Africa. The organization's healthcare initiatives fall within its vision to improve the lives of 3 billion people annually by 2025 . The Community Life Centre Programme has been developed as a strategy to enter the African market.

The Philips Community Life Centre (CLC) is a primary healthcare facility that offers essential health services and products needed to prevent disease, promote health and manage illness, with a particular focus on maternal and child health. The CLC concept begun as a venture in the Philips Eindhoven-based innovation hub in 2003 and was launched as the first holistic healthcare innovation at the Nairobi-based Africa innovation hub. Philips sees the CLC as a community driven and integrated approach to strengthening primary healthcare. Its' proposition is to to collaborate to improve community and primary health across Africa, by extending new or existing health facilities into social and economic community hubs, using exciting innovative and sustainable programs, technologies and services (Philips CLC brochure, p.5).

This case study will focus on 1) the Githurai-Lang'ata CLC-the pilot full CLC located in Kiambu County in Kenya, and 2) the Mandera CLC the CLC-the first commercialized project in the programme. Githurai is a rapidly urbanizing region in the east of Nairobi with a growing population of about 150,000 residents from various backgrounds and income levels. Mandera, on the other hand, is a marginalized county in northern Kenya with one of the world's highest maternal mortality ratio - 3,795 per 100,000 live births, and a catchment population of about 40,000 women and children. Both locations face infrastructural challenges such as access to access to clean water, reliable energy supply, transport mobility and adequate primary and secondary health care services, with Mandera severely affected by these problems. Both CLCs are a result of the transformation of a pre-existing, under-utilized and poorly equipped local health facilities into higher-tier health centres (See Figure 1 for the levels of healthcare delivery outlined in the Kenya Essential Package for Health (KEPH)). Philips integrated medical devices and training, work and patient flows, laboratory equipment, refrigeration, diagnostics and IT applications, supported by solar energy, indoor and outdoor LED-lighting, and clean water supply into these facilities. Philips developed both CLCs in collaboration with the respective local county governments.

A single case study approach was selected to investigate our phenomena of interest, i.e. frugal innovation in a Western MNE entering a sub-Saharan African, its strategic choices and consequences, in a nuanced, empirically-rich and holistic way as proposed by Yin $(2009,50)$. In the context of BOP research and the frugal innovation discourse, the Philips CLC case is unique: 1) Philips N.V., which is a technology firm is diversifying its product offerings by entering the service industry in Africa for the first time, 2) it is entering the state-controlled public service domain of primary healthcare, and thus, it must be not only frugal to cope with extreme resource constraints but also be innovative at the institutional level. The single case study will enable exploration of the normative issues around product innovation and organizational strategy from an interpretative standpoint-a common approach used particularly in empirical studies focused on BOP markets (Andersen and Esbjerg 2020, Ausrød, Sinha, and Widding 2017, Goffin et al. 2019). Further, MNE strategic choice has yet to be investigated through the lens of frugal innovation. Thus, an inductive approach applied through a single case study would yield propositions that could be explored further in future research.

\section{Data Collection}

Data was collected from a variety of sources: participant observation, documentary evidence, and in-depth interviews conducted intermittently between February 2017 and November 2018. Face-to-face, semi-structured interviews were conducted with research scientists and venture managers at the Philips Africa Innovation Hub in Nairobi, Kenya and the corporate offices in Eindhoven and Amsterdam, The Netherlands. These interviews focused on the early-stage conception of the CLC as a venture. They also explored the activities related to the ongoing development and commercialization of the CLC programme in Africa such as co-creation processes, the partnership framework, financing, the CLC roadmap and the future developments. CLC medical staff in the health facility in Nairobi were also interviewed to collect evidence on the day-to-day operations of the CLC. To further validate the perspectives gathered from Philips staff, further interviews were done with officials of the County Government of Kiambu, particularly officials of the county health department that were directly involved in the development, launch and monitoring and evaluation of the CLC. The objective was to interview all actors directly involved with the CLC programme development and deployment, thus there was no overt sampling procedure applied when selecting respondents. Each interview-guided by the standard protocol for capturing emergent themes proposed by Strauss and Corbin (1998)-lasted between 20 minutes and three hours, with some respondents being interviewed multiple times. The interviews were audio-recorded and transcribed verbatim. The list of respondents is included in the appendix.

The interviews were supplemented with participant observation of the operations at the Githurai Lang'ata CLC. While field observation notes were not coded in the data analysis, they were used to validate the findings from the interview data. A wide array of documents was also collected from the Philips offices in Amsterdam, Eindhoven and Nairobi, among them, documentation on the co-creation processes with the community, the components of the CLC, the innovation process followed to develop and commercialize ventures, and project management procedures. The documentation shed light on Philips' internal logic as the CLC evolved and the organizational framework that supported its development. Further documentation on Kenya's and Kiambu County's health system, i.e. the health policy, national and county strategies and investment plans were collected in Kenya to aid in contextualizing the CLC within the health system and evaluating institutional changes under evolution.

To enhance data reliability, two researchers participated in the majority of the interviews, observations and documentary evidence collection. Utilizing multiple sources of data from interviewees in Kenya and The Netherlands, from within Philips and from the local government, data from documentary evidence, and perspectives gathered from participant observation enabled triangulation of the evidence to ensure internal validity of the study as proposed by 
Yin (2009) and Eisenhardt (1989). The data collection strategy was developed in collaboration with two other senior researchers involved in the project with whom follow-up discussions were done to reduce bias and to ensure that there are minimal gaps.

Table 1. Overview of Data Structure

\begin{tabular}{|c|c|c|c|c|}
\hline & \multicolumn{2}{|l|}{ CONTEXTUAL FACTORS (Primary Cycle Coding) } & \multicolumn{2}{|c|}{$\begin{array}{l}\text { STRATEGIC RESPONSES (Secondary } \\
\text { Cycle Coding) }\end{array}$} \\
\hline $\begin{array}{l}\text { Five } \\
\text { Contexts } \\
\text { Framework }\end{array}$ & First-level [descriptive] codes & Analytic codes & $\begin{array}{l}\text { Second-level [descriptive] } \\
\text { codes }\end{array}$ & $\begin{array}{l}\text { Thematic } \\
\text { code }\end{array}$ \\
\hline \multirow[t]{4}{*}{$\begin{array}{l}\text { Local norms } \\
\& \text { value } \\
\text { systems }\end{array}$} & $\begin{array}{l}\text { Heterogeneous customer segments based on ethnicity, } \\
\text { religion, income level, etc }\end{array}$ & \multirow[t]{2}{*}{ Multiplicity of expectations } & \multirow[t]{2}{*}{$\begin{array}{l}\text { Adopting a modular design } \\
\text { approach to cater for } \\
\text { heterogeneous needs }\end{array}$} & $\begin{array}{l}\text { Shaping } \\
\text { the } \\
\text { context }\end{array}$ \\
\hline & $\begin{array}{l}\text { Different ways of delivering health services in different } \\
\text { regions }\end{array}$ & & & \\
\hline & \multirow[t]{2}{*}{$\begin{array}{l}\text { Participation of herbalists, birth attendants, } \\
\text { community health workers and other informal } \\
\text { actors in primary care }\end{array}$} & \multirow[t]{2}{*}{$\begin{array}{l}\text { Deeply embedded informal } \\
\text { institutions }\end{array}$} & $\begin{array}{l}\text { Co-opting local healthcare } \\
\text { governance structures and } \\
\text { Community Health Workers }\end{array}$ & \multirow[t]{3}{*}{$\begin{array}{l}\text { Adapting } \\
\text { to the } \\
\text { context }\end{array}$} \\
\hline & & & $\begin{array}{l}\text { Co-creation with the local } \\
\text { community }\end{array}$ & \\
\hline \multirow[t]{3}{*}{$\begin{array}{l}\text { Regulatory } \\
\text { environment }\end{array}$} & Tiered health system framework & Established formal institution & $\begin{array}{l}\text { Aligning the design of the } \\
\text { CLC to the existing policy } \\
\text { framework }\end{array}$ & \\
\hline & Poor coordination in referral system & \multirow[t]{2}{*}{$\begin{array}{l}\text { Inconsistencies/absence/weakness } \\
\text { in the regulatory framework and } \\
\text { other formal institutions }\end{array}$} & $\begin{array}{l}\text { Experimentation and } \\
\text { innovation beyond } \\
\text { the health policy } \\
\text { framework }\end{array}$ & \multirow[t]{3}{*}{$\begin{array}{l}\text { Shaping } \\
\text { the } \\
\text { context }\end{array}$} \\
\hline & Decentralization of primary healthcare & & $\begin{array}{l}\text { Co-creation with } \\
\text { community where local } \\
\text { needs mismatch policy } \\
\text { framework }\end{array}$ & \\
\hline \multirow[t]{4}{*}{$\begin{array}{l}\text { Product } \\
\text { market }\end{array}$} & Lack of reliable data on customer needs/preferences & $\begin{array}{l}\text { Inconsistencies/absence/weakness } \\
\text { in the regulatory framework and } \\
\text { other formal institutions }\end{array}$ & $\begin{array}{l}\text { Co-creation with } \\
\text { community }\end{array}$ & \\
\hline & Sparsely populated, extreme environments & \multirow[t]{3}{*}{ Resource constraints } & $\begin{array}{l}\text { Design for excellence, } \\
\text { value engineering }\end{array}$ & \multirow{3}{*}{$\begin{array}{l}\text { Adapting } \\
\text { to the } \\
\text { context }\end{array}$} \\
\hline & \multirow{2}{*}{$\begin{array}{l}\text { Under- } \\
\text { developed health infrastructure and primary healthcare } \\
\text { market }\end{array}$} & & & \\
\hline & & & $\begin{array}{l}\text { Forming partnerships with } \\
\text { local government }\end{array}$ & \\
\hline \multirow[t]{3}{*}{$\begin{array}{l}\text { Labour } \\
\text { market }\end{array}$} & Different work ethic and culture & Multiplicity of expectations & $\begin{array}{l}\text { Hiring foreign } \\
\text { nationals from parent } \\
\text { country in managerial roles }\end{array}$ & $\begin{array}{l}\text { Shaping } \\
\text { the } \\
\text { context }\end{array}$ \\
\hline & \multirow[t]{2}{*}{ Shortages in local skilled technical staff } & \multirow[t]{2}{*}{ Resource constraints } & $\begin{array}{l}\text { Hiring local health } \\
\text { professionals in R\&D }\end{array}$ & \multirow{3}{*}{$\begin{array}{l}\text { Adapting } \\
\text { to the } \\
\text { context }\end{array}$} \\
\hline & & & $\begin{array}{l}\text { Training and } \\
\text { development of local hires }\end{array}$ & \\
\hline \multirow[t]{2}{*}{$\begin{array}{l}\text { Capital } \\
\text { market }\end{array}$} & $\begin{array}{l}\text { Limited opportunities to raise capital } \\
\text { from local financial markets }\end{array}$ & \multirow[t]{2}{*}{ Resource constraints } & $\begin{array}{l}\text { Fundraising from } \\
\text { development partners and } \\
\text { aid agencies }\end{array}$ & \\
\hline & Budgetary constraints in local governments & & $\begin{array}{l}\text { Forming partnerships with } \\
\text { local governments to use } \\
\text { local public funds }\end{array}$ & \\
\hline
\end{tabular}

\section{Data analysis}

Data analysis was conducted in three main stages during which we went back and forth between the data and the emerging theoretical arguments (Tracy 2020, Miles, Huberman, and Saldana 2013). We started by constructing a narrative account of developments associated with the CLC by organizing raw data chronologically. From this narrative account, we used the 'Five Contexts framework' developed by Khanna et al. (2005) to identify and descriptively code contextual issues into the five domains, i.e. the product market, regulatory framework, local norms, labour market and capital market. For instance, under local norms and value systems, examples of codes at this stage included Heterogeneous customer segments based on ethnicity, religion, income level, etc. and Different ways of delivering health services in different regions. See the data structure in Figure 1 for a list of the descriptive codes. Through the process of axial coding, we then grouped similar contextual factors into more abstract analytic codes. For example, multiplicity of expectations was a common theme arising from the fact that local norms were diverse due to heterogeneous groups and primary care services in the regions studied. Other emergent themes from each of the 'Five Contexts framework' domains are presented in Table 1. 
The second cycle of coding focused on identifying specific strategic responses of Philips N.V. to the contextual factors identified in the previous cycle. Through a second review of the whole dataset, further descriptive codes were generated, for example, adopting a modular design approach to cater for heterogeneous needs or co-opting local healthcare governance structures and Community Health Workers. These strategies were linked directly to the contextual factors identified in the primary coding cycle. In Table 1, linked codes are presented in the same row, such that each strategic response is connected to a specific contextual factor. In order to determine whether these strategic responses were focused on either adapting to the context or shaping the context, we analyzed them interpretatively to see if there is a pattern of decision making. This process was inductive and recursive so as to identify the predictive factors as more abstract, theory-rich constructs. Specifically, we explored the rationale underlying Philips responses and the related scope of contextual factors. We then found, for example, that strategic responses that addressed established formal institutions and deeply entrenched informal institutions tended to adapt to local conditions rather than shape them. From these findings, we made some propositions on the expected behaviour of an MNE to pressures in a BOP context.

Finally, we explored the consequences or outcomes of these strategic choices on the Philips organisation. We engaged in a selective coding process in another review of the dataset to find ways in which the strategies identified in the second cycle of coding resulted in tensions or dilemmas within the organization. We also engaged in axial coding to categorize these outcomes as internal or external, and short-term or long-term.

This coding process was conducted by one researcher. However, to avoid misinterpretations and ensure that the final themes adequately reflect the phenomena, the findings were shared with three of the interviewees from Philips and with fellow researchers in the project.

\section{Findings}

Philips' overall strategy with the CLC programme was to improve access to primary care by strengthening the backbone of the healthcare system by upgrading existing primary care facilities into CLCs, equipping community health workers and streamlining their link with CLCs and supporting tertiary facilities (Philips brochure: Working together to transform Healthcare in Africa 2015). The narrative below begins by highlighting the contextual factors in the primary healthcare space in Kenya, Philips strategic responses during the frugal innovation process, and the predictive factors. Subsequently, the findings present the emerging intra-organisational tensions as Philips implemented the strategies identified.

\section{Contextual Factors and Strategic Responses}

\section{Local norms, value systems and practices}

Historically, rural communities and low-income households in urban areas in Kenya relied on traditional methods of healthcare. Examples include domestic and folk medicine, and relatively advanced traditional medical systems, some of which have evolved into somewhat professionalized informal healthcare services. These norms are still in effect, particularly in rural areas and in low-income urban areas in Kenya where primary care services are currently underdeveloped.

At the core of Philips CLC strategy is community engagement, first through co-creation, and subsequently through community participation in the governance of CLC facilities. Philips' efforts to co-create with the local community adapted the value proposition of the CLC to community needs. Philips further aligned with local norms around healthcare delivery and management by leveraging existing institutions and relations. Co-optation efforts were at two levels: recruiting Community Health Workers (CHW) to use the Philips backpacks and equipment in their routine household health visits, and adopting pre-existing local health committees as the governance framework for the CLC. These strategies gave legitimacy to CLC in the community by fostering local ownership even though the facilities had a clear Philips brand image.

Findings on the CLC programme also show that Philips sought to adapt product development to these norms and value systems by embracing modularity. Modularity means that core primary care services are at the core of the standard design, while auxiliary services or the different modes of delivery can be customized or added on based on the specific needs and circumstances of any particular area and health facility. The modular design is seen as a way to balance efforts to adapt to local needs and developing a standardized solution, as the Senior CLC Research Scientist intimated:

We still retain as something which is going to be unique to the facility, and what elements are going to go as part of a module and negotiable. And then we come up with different standardization models.

The modular design also enables Philips to leverage knowledge gathered from one site to develop the core and auxiliary elements further. Deploying it in the field, you optimize between what you can do locally and what you can leverage from other places (Head of Research Africa, Philips).

\section{The product market}

Philips considered the existing resource constraints and the underdeveloped primary care product market as an opportunity to introduce a new frugal paradigm of primary healthcare delivery. This is evident in the overarching strategy of the CLC venture to develop a community-level healthcare solution that easily adapts to the different community needs in different African villages (Internal company report, 2014). This effort to adapt was evident in Philips's effort to re-engineer its products and processes, and to form partnerships to overcome market information deficits. In this regard, Philips adopts frugal engineering as a mindset.As the Head of Research Africa explains: 
Coming from Eindhoven where we have amazing infrastructure, I cannot afford that infrastructure here in Kenya. We talk about the acceptability and affordability in how a product should be created, then we need to look into cost-effectiveness. And since I started work for low resource setting, Value Engineering and Design for Excellence are very key.

Philips Innovation Services defines Design for Excellence as a holistic methodology to radically reduce product cost and increase value. The design for excellence approach, abbreviated DfX, is used to 'shape markets and opportunities' by launching 'a more expensive product type when there were still very successful low-cost versions in the market'. Within the DfX toolbox, Philips adopts 'Value Engineering' as a mindset to measure costs and value during product development. Value engineering was applied to design and manufacture frugal technologies used in the CLC such as battery-powered ultrasound machines, vital signs monitors, fetal dopplers, among other equipment that are robust to off-grid environments. Similarly, the Philips CLC outreach kit was designed to adapt to the field conditions of community health workers by being dust and water-resistant, strong and comfortable for portability. To be able to develop such high-tech solutions adapted for low-tech environments, Philips is leveraged its internal engineering capabilities.

\section{The regulatory environment}

Kenya, like many developing countries, has a tiered healthcare system (see Figure 1). However, there is poor coordination within this tiered system to facilitate referral and exchange of patient information. Further, primary healthcare has been decentralised to local governments which unfortunately have limited budgets to develop or maintain the health facilities. Before launching the first CLC, Philips invested considerable effort to learn about the health system in Kenya and other African countries. Such a process entailed developing an in-depth understanding of the regulatory frameworks in place, national and local government strategies, and the challenges that these governments face to develop and implement related policies.In order to align the design of the $C L C$ to the existing regulatory framework, the Philips Africa Innovation Hub was keen on adapting to the Kenya Health Policy 2014-2030 which gives direction to ensure significant improvement in the overall status of health in Kenya. Evaluation of the CLC programme shows that throughout the CLC development process, Philips aligned their interventions to the broad outlines of the Kenya Essential Package for Health (KEPH), first in positioning upgraded facilities within the KEPH levels or tiers and aligning the type of services provided accordingly (See Figure 1 for the hierarchy of health facilities in Kenya). For instance, Philips had the Githurai-Langata CLC gazetted as a Level 3 facility and the Mandera CLC as a Level 2 facility. The Head of Research Africa was explicit in saying that:

We start with an assessment which defines what gets into [the CLC]. At the minimum, the facility needs to have requirements stipulated in the Kenya Essential Package for Health. If it [the facility] is connected to the grid, then you don't need energy. If it has water, you don't need to provide the water. So the assessment will define what elements get into it, but based indeed on that essential package and the local needs at play.

However, as his last statement above indicates, the design of the CLC is not only aligned to the KEPH, but also to the local needs at play. This implies that local needs potentially go over and above the stipulations of the policy-a matter that opens up opportunities for innovation outside the policy stipulations, and thus opportunities to shape the policy environment via demonstration effects. Further, Philips, in conjunction with the county governments, found opportunities to innovate within this policy framework in a way that may influence the development of primary healthcare delivery. Such policy experimentation enabled Philips to further engage in advocacy for innovation within the KEPH framework. Philips also engaged in co-creation with community members to identify mismatches between local needs or expectations with both Philips standards and the local government's standards. Such a bottom-up approach gave legitimacy to the resulting CLC design, even though it may conflict with expectations on both sides. In summary, the findings show that Philips adopted both strategies to adapt to and to influence the regulatory framework.

\section{The labour market}

Human resources employed to develop, test and implement the CLC venture were pivotal to the envisioned success of the venture, particularly in making it locally relevant. Thus, available human resources in the labour market in Kenya were considered crucial to the MNE, not only with regard to their knowledge capabilities on primary healthcare and the policy environment, but also technical capabilities that matched the requirements of realizing the CLC, e.g. managing co-creation processes and related user studies, developing locally relevant medical technology and information systems, and integrating the CLC components in a way that made sense in different low resource settings.

At Philips, we believe that our workforce should be a reflection of the society in which we operate, a reflection of our customers, and the markets we serve (Philips Annual Report, 2017)

Philips began by hiring local health professionals in R\&D. In this regard, Philips executives lamented the chronic capacity deficiency in Kenya. Initially, research staff from Philips' business units in countries with contexts somewhat similar to Kenya, e.g. India, China and South Africa were brought in to help build the local capacity. The Head of the Africa Innovation Hub explained the need to set up an innovation lab in Africa that employed local scientists to mitigate the risk of mismatched products. As he explained, if you want to get local insights, you need to have local people, in a local R\&D lab like the one we have today. Local research scientists also came into Philips with tacit knowledge on how to engage local stakeholders. The local hires validated and further developed the value proposition and the roadmap, particularly where the European staff were unfamiliar with the context and had somewhat naïve expectations about the theory of change. Finally, Philips invested considerable resources to train local hires to raise their capacity, thus adapting to the constraint in the labour market.

\section{The capital market}


Various Philips executives observed that raising funds from African capital markets for large investments in the primary healthcare space is challenging given the absence of local venture capitalists, and varying priorities and constraints of local financial institutions. Public healthcare expenditure in most Africa countries is also generally low.

[Financing] is a challenge that [local governments] have even though the willingness is there. And this is a new field and in general there is a challenge on how to finance this type of solutions.

To raise capital, Philips explored public private partnerships with national and local governments which, though limited, have budgets for primary healthcare development and for related recurrent costs such as facility management and human resources. Philips' first CLC in Kenya was established through a publicprivate partnership arrangement in which the local government supplied the land, labour to refurbish the facility and construct building extensions, supply water, and recurrent expenditure such as staffing costs and supply of medical commodities. Philips absorbed the investment in medical, laboratory and refrigeration equipment, and the energy, lighting and IT solutions. Philips has also explored a Management Equipment Services model that enables local governments to make regular, prearranged payments for leased equipment over an agreed contractual period. Philips also adapted to constraints in the capital market by exploring various donor-led financing options. For instance, to finance the Mandera CLC, Philips and the local county government sourced for capital from The United Nations Population Fund (UNFPA). Internally, the need to develop fundraising procedures within the CLC end-to-end process became pertinent, as explained by the Head of Research Africa:

We deal with donors many times through calls for proposals. Sometimes we need to approach them and develop a case which we can pitch. This is particularly related to the M2O part, its more related to development projects and funding. Many of the donors actually have funds or budgets available for specific areas, and that can be primary care.

In sum, Philips' effort to fundraise through external markets is an obvious strategy to adapt to contextual constraints by mobilizing external resources. However, the type of public-private partnerships that Philips has negotiated in primary the healthcare arena is revolutionary as it has the potential to influence the structure of primary care investments in Kenya, and by extension, in Africa.

\section{Predictive Factors}

The preceding section demonstrated that, to respond to the local conditions in two regions in Kenya, Philips adopted both market adaptation and market shaping strategies through its CLC programme. Analysis of those strategies and tactics signals a pattern of decision making presented below.

\section{Adapting to the Context}

Deeply embedded informal institutions and established formal institutions: The case findings have shown that local norms and value systems in healthcare delivery at the community level are deeply ingrained. As a foreign entrant into a BOP setting, changing those norms in the short-term, particularly in primary care in rural areas, is a risky strategy. Recognizing this, Philips instead chose to collaborate with and co-opt local communities to learn about local primary care norms and needs. In this way, the MNE was able to align with local norms to gain legitimacy of their new intervention in the BOP context. Similarly, the case findings show Philips aligning with 'The Kenya Essential Package for Health (KEPH)', which is part of the Kenya Health Policy for similar reasons: to gain legitimacy for the CLC within the existing formal institutional framework.

P2. When an MNE is confronted with deeply embedded informal institutions or established formal institutions, it is likely to respond by adapting to those institutions in order to develop a locally embedded product.

Resource constraints: The case findings show that as a foreign MNE, Philips had to confront significant resource constraints to design and implement the CLC as a primary care intervention. Thus, the organization is compelled to respond by, for instance, engaging in frugal engineering as a response to deficiencies in the product market. The organization may also hire local staff to gain local knowledge capabilities, and train new hires to address any skill deficits. Further, the organization may adapt to underdeveloped capital markets by raising capital externally to facilitate usually significant capital investments in research, development and implementation. These strategic choices were geared towards deploying resources to adapt to local resource deficiencies.

P4. When an MNE engaging in frugal innovation in a BOP setting confronts severe resource constraints, it is likely to respond by adapting the context by mobilizing internal resources.

\section{Shaping the Context}

A multiplicity of expectations: Multiple expectations arise when an actor is dealing with heterogeneous stakeholders. Given that the CLC programme was to be scaled up and rolled out in different regions in Kenya, but also in sub-Saharan Africa, it would be too costly to customize each facility to each of those expectations. Thus, Philips opted to use a modular design approach to develop locally relevant solutions that can be standardized to facilitate scale-up. In this way, the core elements of the CLC shape of influence how healthcare services are consumed.

\section{P1. When an MNE faces multiple expectations from heterogeneous groups in a BOP context, it is likely to make the strategic choice to shape those} expectations to successfully enter the market and scale up.

Inconsistencies, absence or weaknesses in the regulatory framework: In the process of conforming to the existing institutional framework, Philips discovered various weaknesses in the system, among them, poor coordination in the referral system. These weaknesses were due to institutional voids in the system, which created an opportunity for Philip to make interventions with the CLC that have implications for the policy framework. For instance, Philips was able to 
experiment with new technology beyond the policy stipulations to address existing primary care needs, while co-opting policymakers in the learning process with the view of scaling up the CLC as a new healthcare delivery organizational form.

P3. When an MNE engaging in frugal innovation in a BOP setting encounters institutional voids in the regulatory framework, it is likely to respond by influencing the context by filling those institutional voids.

\section{Tensions emerging from the strategic orientations}

For Philips deploying the two strategic orientations resulted in some tensions and dilemmas at the intersection of the parent organisation and the local affiliate. Entering the BOP was not business as usual, it was also a disruptive process within the organisation. It called for a re-examination of taken-forgranted organisation processes and philosophies. Below are the tensions that emerged as the CLC was being deployed in Kenya:

New R\&D capabilities (technology push vs demand-pull capabilities)

As already seen, Philips leveraged its internal engineering capabilities to develop high-tech frugal technologies that fit the primary healthcare product market. However, Philips realized that deploying frugal technologies in a coherent or integrated solution requires more than a technology-push R\&D approach that Philips has become accustomed to while serving markets in industrialized settings. The organization needed to develop a new set of competencies to implement a demand-driven, bottom-up approach based on local needs assessment and co-creation efforts. To address this challenge, Philips has to acquire new capabilities to implement a demand-pull R\&D framework as a complement to its conventional technology-push approach. Addressing this challenge would require a review, and possibly, a restructuring of the internal organizational resources and norms The Senior CLC Research Scientist, Philips explains further:

It has taken us three years to really figure out what it takes to have an operational CLC. Now we are trying to work in the organization to figure out how we can fit the requirements or the norms set within the organization. It might seem very simple, but the process of transforming yourself internally to cater to a population through one solution is a big risk. We are trying to define a new way to do business.

Tension in the internal commercialization operations: silo-based approach vs solution-oriented approach

Philips' operations are structured around a silo-based approach where each product line has dedicated operational infrastructure ranging from R\&D to revenue management. Philips has been building and selling high-margin products such as MRI machines through dedicated business units. However, the CLC as a proposition is packaged not as a product or combination of products, but as a 'solution' that contains various medical devices, laboratory and refrigeration equipment, energy and lighting technologies, and IT solutions. Thus, an integrated product management approach, not only for R\&D, but for the entire product development and commercialization process, was required. As the Venture Manager of the CLC elaborated:

It means that certain organizational tendencies need to be broken. So first, you can't work in silos. You can no longer say that that ultrasound is a different business unit, or patient care and monitoring is a different unit, and they have their own R\&D, they have their own P\&L, they have their own individual ways of working. We need to work together. And that is a big responsibility, because we are talking about changing our way of working for an organization which has really set itself up for more than 100 years.

In order to respond to these operational challenges, Philips developed a new three-phase 'end-to-end process' for the CLC scaling programme. This is a workflow programme that caters to the complexity of deploying a solution in the African context and takes into account the large variety of clients and partners (governments, donors, development banks, etc.) engaged in different stages of realizing a CLC. It begins with an Idea-to-Market (I2M) phase that streamlines R\&D processes, followed by the Market-to-Order (M20) phase where a value proposition is developed, and an assessment of customer needs is done and translated into an order. The final phase, Order-to-Cash ( $\mathrm{O} 2 \mathrm{C})$, spans from the moment there is a handshake between Philips, its partners and the customer to the point an order is formalized. Thus, it covers product and service delivery, manufacturing execution, logistics, warehousing, and related financial transactions. An implementation phase follows, where many partners are also engaged to supply and realize the CLC, and to service it on an ongoing basis. This end-to-end process was found to be useful not only for the CLCs in sub-Saharan Africa, but also for other products rolled out in other markets.

\section{Tension between standardization and customization to scale the intervention}

The value of co-creation is highly appreciated at the African Innovation Hub as a way to adapt the CLC to local norms and local resource constraints. However, findings from interviews indicated that executives at Philips corporate did not share this perspective, co-creation was expensive, and its return on investment was yet to be established. They preferred to manufacture standard health technologies that can be sold at high volumes in new markets. Cocreation costs involve hiring many well-paid, highly skilled scientists capable of implementing time-consuming participatory approaches, sending them to remote hardship areas which exacerbates costs, and designing CLCs from the ground-up. To balance these interests, one viable alternative was to cater to a specific range of customer (Senior CLC Research Scientist), particularly when a large donor organization that is willing make a capital investment to implement CLCs on a large scale so as to demonstrate integrative change in primary healthcare. This alternative was alluring due to its economies of scale that lower the cost of co-creation per facility. According to the Philips Head of Research Africa, the objective is to find the balance between what is locally relevant, and what is cost effective.

To further alleviate the high cost of scaling the co-creation approach, Philips started to develop a standardized way of engaging with the community that is more sustainable and cost-effective. This application, based on information technology, would be used to investigate workflows and patient flows in local 
facilities, assess local challenges, and collecting insights from community members. The IT-based tool would be used remotely instead of sending someone to a dangerous place to do co-creation (Head of Research Africa, Philips), and data collected would feed into the CLC design process.

Tension in quality standards: EU-oriented vs local standards

In the R\&D process, further tensions emerged on whether to impose Philips internal quality standards developed in its European markets on the African context. New frugal products aimed for African and Asian markets were subjected to prolonged, bureaucratic European-based quality standards that complicated and delayed deployment. For instance, the Philips Children's Automated Respiration Monitor (ChaRM), which was developed by the Africa Innovation Hub for use in the CLC, was subjected to heavy regulatory approval processes for which capacity lacked in Africa and in India where the device was manufactured. To conform to the European standard, the Indian factory had to be EU accredited, which entailed worker training and new bureaucracies. These processes delayed production and subjected the Philips $\mathrm{CHaRM}$ to competition from China where such procedures are either relaxed or non-existent. The consequences are, as the Venture Manager CLC describes:

It makes us slow, very slow. It makes us very expensive, and the question is, can we really compete in this market with such heavy burden that we shouldn't carry. In the end, you probably have wonderful quality product that is completely regulated and what not, but how competitive are you?

\section{Tension between local and Philips' corporate organizational culture}

As seen earlier, hiring local staff contributes enabled Philips to learn about the local environment in order to adapt the CLC accordingly. Similarly, the Philips Africa Innovation Hub was set up to have close collaboration with the Philips research labs in Bangalore, Shanghai and Eindhoven to facilitate open innovation and knowledge exchange. As the Head of Research Africa remarked:

I had people from India, Netherlands, but locals also need to do the work to build the capacity. And for me, I was also new in the ecosystem so to find the right people was not easy. It's such a challenge.

While entering the primary healthcare space in Africa, Philips has found itself grappling with whether and how to propagate its organizational culture on their commercial operations in Africa while re-orienting itself to the local mindset and local challenges. Philips strategically had European staff in managerial roles in the Africa Innovation Hub to ensure that the Philips organizational culture is sustained. The CLC Venture Manager expounded the dilemma as follows:

As a western company like like Philips is, if you do business in Africa, you have to choose. Either you do it the African way or you do it the western way. We have many qualified African staff, although most of our leaders are non-Africans. But of course, our African staff are working in a European system, because the Philips system is a European system. So it's very difficult. Mostly the African people will have difficulty... 'why on earth do we have to do things in this weird way?' because it's different from what they were used to.

Here, a tension emerges between adapting the business to the local environment by hiring local staff, while maintaining the internal organizational culture oriented towards a European setting.

\section{Discussion And Conclusion Theoretical implications}

This paper extends the literature on strategic choices, responses or orientations in the base-of-the-pyramid. Previously, much of the literature on frugal innovation entrepreneurship in BOP contexts and business model development assumes that businesses adapt to new contexts by redesigning or developing new technologies and business models appropriate to local conditions (Simanis and Hart 2009, Zeschky, Widenmayer, and Gassmann 2011). However, there is increasing acknowledgment that enterprises may also shape the context by launching disruptive products that change the configuration of the business ecosystem and local institutions (Hwang and Christensen 2008, Ramdorai and Herstatt 2015, Rao 2013). While this literature has already shown that multinational enterprises can adopt either a market adaptation or market shaping strategy, there is less attention paid to when these strategies are deployed, and the patterns of decision making at the organisational level. The paper offers predictive factors that could determine the strategic responses in BOP contexts, and generates several hypothesis in this regard.

This paper further contributes to the frugal innovation literature, which at the moment, lacks rigorous, in-depth analytical case studies on organisational processes associated with new product development (Hossain 2018, Agarwal et al. 2017, Pisoni, Michelin, and Martignoni 2018). The paper introduces insights from the well-developed BOP literature to understand frugal innovation processes in their context. The paper further focuses on the service sector that has largely been ignored in the frugal innovation discourse. Findings reveal that frugal innovation is not only geared towards adapting to resource constraints as previously discussed (See for instance Cunha et al. 2014, Rao 2013, Sehgal, Dehoff, and Panneer 2010, Zeschky, Widenmayer, and Gassmann 2011), but also has an institutional focus and effect.

Finally, the paper sheds new light on intra-organisational dynamics within multinationals that result when different strategic orientations are implemented in new BOP contexts. The study shows that shifting internal organisation logics can be a challenging task due to cognitive biases entrenched by operating successfully in markets that are fundamentally different from the BOP. However, given that MNEs have largely saturated their home country markets and are actively looking for new markets in the BOP, these tensions can not be ignored.

\section{Managerial implications}


Practically, this study offers managers a useful toolkit that could inform how they could strategically navigate the pressures of BOP environments. The findings inform managers that they can adopt diverse, but targeted strategic orientations when dealing with different institutional and resource pressures in BOP markets. Where there are severe resource constraints, the organization may opt to mobilize internal resources to develop frugal interventions that adapt to those constraints. Managers should be cautious about immediately trying to shape of influence deeply entrenched institutions unless there are clear weaknesses or inconsistencies in that environment.

Managers can also shift the organisation's strategic orientation in different domains upon learning about the local context, acquiring new resources, and when changes occur in the external environment. For instance, certain contextual factors may imply that only market adaptation can be applied as a strategy. However, immersing oneself in the context to learn about opportunities such as institutional voids can present an opportunity to change the strategy to a market shaping one. In other words, managers should be willing to experiment in their new local contexts to find the best course of action.

Strategic orientations can also be layered, and as such, may differ across the organisation during the early phases of developing and launching a frugal innovation. At the subsidiary or local affiliate level, there is a clearer appreciation of the fact that any solution developed must adapt to local resource constraints and the institutional environment. This could be due to the fact that the local organisation is locally embedded, and it must routinely confront these constraining factors in its direct interactions with local communities and governments (Ciabuschi, Holm, and Martín Martín 2014). Its search for legitimacy is on more temporal and micro-level. The parent organisation, however, adopts a broader macro perspective that seeks to induce changes in the new context by influencing the institutional environment. This reflects the nested hierarchical nature of MNE strategy. Thus, managers must tactfully navigate these layers during the product development process.

Similarly, layering of the strategic orientation may also have a temporal aspect. Managers can use market adaptation to enter the market, learn about the market, and explore how a scalable yet contextually relevant product can be developed. This justifies the need to make large investments towards co-creation processes, frugal engineering, training and development of local hires, and community outreach in order to understand how the product fares as an intervention in the existing environment. The market adaptation strategy can be seen as a way to gain legitimacy in the new context and get local ownership from policy makers and the community. Upon proof of concept, i.e. a scalable product, the organisation would aim to deploy and scale up a more standardised solution. To pave way for such a solution in new contexts, the organisation may more overtly engage in efforts to influence local institutions such as regulation and local norms. However, this approach is prohibitively costly and high risk if the proof of concept is not achieved and legitimacy is not garnered.

\section{Limitations and further research}

While this study aids our understanding of the nature of frugal innovation strategy in BOP contexts, it has some limitations that could be addressed in future research. The contributions are drawn from a single in-depth case study in the primary healthcare sector, and thus, the empirical findings cannot be directly generalized beyond similar contexts and public sectors. Nevertheless, the study has generated propositions that could be analysed whenever an MNE is entering a BOP context by doing frugal innovation. Further research could investigate whether similar studies in other sectors and contexts will generate similar results.

The study also focused on a powerful MNE with vast internal resources and capabilities and access to external resources (e.g., more capital, partnerships, etc), and clout to influence institutions. Further research can explore how a less powerful MNE, or a local enterprise make strategic choices when confronted with similar contextual factors.

\section{Abbreviations}

$\begin{array}{ll}\text { BOP } & \text { Base of the pyramid } \\ \text { ChaRM } & \text { Philips Children's Automated Respiration Monitor } \\ \text { CHW } & \text { Community Health Workers } \\ \text { CLC } & \text { Philips Community Life Centres } \\ \text { DfX } & \text { Design for excellence approach } \\ \text { EU } & \text { European Union } \\ \text { I2M } & \text { Idea-to-Market } \\ \text { KEPH } & \text { Kenya Essential Package for Health } \\ \text { M2O } & \text { Market-to-Order } \\ \text { MNEs } & \text { Multinational enterprises } \\ \text { O2C } & \text { Order-to-Cash } \\ \text { R\&D } & \text { Research and Development }\end{array}$




\section{Declarations}

\section{Availability of data and materials}

The data that support the findings of this study are available on request from the author. The data are not publicly available as they contain information that could compromise the privacy of research participants.

\section{Competing interests}

The author declares that they have no competing interests.

\section{Funding}

This work was supported by the Netherlands Organization for Scientific Research [NWO grant number 313-99-314].

\section{Authors' contributions}

This is a single authored paper, thus all contributions were made by the sole author.

\section{Acknowledgements}

I would like to thank Peter Knorringa for his helpful comments on an earlier version of this paper.

\section{References}

1. Agarwal, N., and A. Brem. 2012. Frugal and Reverse Innovation - Literature Overview and Case Study Insights from a German MNC in India and China. In 2012 18th International ICE Conference on Engineering, Technology and Innovation (ICE), 1-11. https://doi.org/10.1109/ICE.2012.6297683.

2. Agarwal, N., M. Grottke, S. Mishra, and A. Brem. 2017. A Systematic Literature Review of Constraint-Based Innovations: State of the Art and Future Perspectives. IEEE Transactions on Engineering Management 64 (1): 3-15. https://doi.org/10.1109/TEM.2016.2620562.

3. Andersen, Poul Houman, and Lars Esbjerg. 2020. Weaving a Strategy for a Base-of-the-Pyramid Market: The Case of Grundfos LIFELINK. Business Strategy and the Environment n/a (n/a). https://doi.org/10.1002/bse.2604.

4. Ausrød, Vegar Lein, Vivek Sinha, and Øystein Widding. 2017. Business Model Design at the Base of the Pyramid. Journal of Cleaner Production 162 (September): 982-96. https://doi.org/10.1016/j.jclepro.2017.06.014.

5. Baker, Ted, and Reed E. Nelson. 2005. Creating Something from Nothing: Resource Construction through Entrepreneurial Bricolage. Administrative Science Quarterly 50 (3): 329-66.

6. Banerjee, Abhijit V., and Esther Duflo. 2007. The Economic Lives of the Poor. Journal of Economic Perspectives 21 (1): 141-68. https://doi.org/10.1257/jep.21.1.141.

7. Battilana, Julie, Bernard Leca, and Eva Boxenbaum. 2009. How Actors Change Institutions: Towards a Theory of Institutional Entrepreneurship. The Academy of Management Annals 3 (1): 65-107. https://doi.org/10.1080/19416520903053598.

8. Bhatti, Yasser Ahmad. 2012. What Is Frugal, What Is Innovation? Towards a Theory of Frugal Innovation. SSRN Scholarly Paper ID 2005910. Rochester, NY: Social Science Research Network. http://papers.ssrn.com/abstract=2005910.

9. Boisot, Max, and John Child. 1999. Organizations as Adaptive Systems in Complex Environments: The Case of China. Organization Science 10 (3): 23752. https://doi.org/10.1287/orsc.10.3.237.

10. Bound, Kirsten, and lan WB Thornton. 2012. Our Frugal Future: Lessons from India's Innovation System. Nesta London. http://www.nesta.org.uk/sites/default/files/our_frugal_future.pdf.

11. Brem, Alexander, and Pierre Wolfram. 2014. Research and Development from the Bottom up - Introduction of Terminologies for New Product Development in Emerging Markets. Journal of Innovation and Entrepreneurship 3 (1): 9. https://doi.org/10.1186/2192-5372-3-9.

12. Bruton, Garry D., David Ahlstrom, and Han-Lin Li. 2010. Institutional Theory and Entrepreneurship: Where Are We Now and Where Do We Need to Move in the Future? Entrepreneurship Theory and Practice 34 (3): 421-40. https://doi.org/10.1111/j.1540-6520.2010.00390.x.

13. Chesbrough, Henry. 2010. Business Model Innovation: Opportunities and Barriers. Long Range Planning, Business Models, 43 (2-3): $354-63$. https://doi.org/10.1016/j.Irp.2009.07.010.

14. Ciabuschi, Francesco, Ulf Holm, and Oscar Martín Martín. 2014. Dual Embeddedness, Influence and Performance of Innovating Subsidiaries in the Multinational Corporation. International Business Review 23 (5): 897-909. https://doi.org/10.1016/j.ibusrev.2014.02.002.

15. Cunha, Miguel Pina e, Arménio Rego, Pedro Oliveira, Paulo Rosado, and Nadim Habib. 2014. Product Innovation in Resource-Poor Environments: Three Research Streams. Journal of Product Innovation Management 31 (2): 202-10. https://doi.org/10.1111/jpim.12090.

16. Dahan, Nicolas, Jonathan Doh, and Terrence Guay. 2006. The Role of Multinational Corporations in Transnational Institution Building: A Policy Network Perspective. Human Relations 59 (11): 1571-1600. https://doi.org/10.1177/0018726706072854. 
17. Dembek, Krzysztof, and Nagaraj Sivasubramaniam. 2016. A Systematic Review of the Bottom of the Pyramid Literature. Academy of Management Proceedings 2016 (1): 18011. https://doi.org/10.5465/ambpp.2016.18011abstract.

18. Eisenhardt, Kathleen M. 1989. Building Theories from Case Study Research. The Academy of Management Review 14 (4): $532-50$. https://doi.org/10.2307/258557.

19. Ernst, Holger, Hanna Nari Kahle, Anna Dubiel, Jaideep Prabhu, and Mohan Subramaniam. 2015. The Antecedents and Consequences of Affordable Value Innovations for Emerging Markets. Journal of Product Innovation Management 32 (1): 65-79. https://doi.org/10.1111/jpim.12171.

20. George, Gerard, Anita M. McGahan, and Jaideep Prabhu. 2012. Innovation for Inclusive Growth: Towards a Theoretical Framework and a Research Agenda. Journal of Management Studies 49 (4): 661-83. https://doi.org/10.1111/j.1467-6486.2012.01048.x.

21. Goffin, Keith, Pär Åhlström, Mattia Bianchi, and Anders Richtnér. 2019. Perspective: State-of-the-Art: The Quality of Case Study Research in Innovation Management. Journal of Product Innovation Management 36 (5): 586-615. https://doi.org/10.1111/jpim.12492.

22. Hart, Stuart, Sanjay Sharma, and Minna Halme. 2016. Poverty, Business Strategy, and Sustainable Development. Organization \& Environment 29 (4): 401-15. https://doi.org/10.1177/1086026616677170.

23. Hossain, Mokter. 2018. Frugal Innovation: A Review and Research Agenda. Journal of Cleaner Production 182 (May): $926-36$. https://doi.org/10.1016/j.jclepro.2018.02.091.

24. Hwang, Jason, and Clayton M. Christensen. 2008. Disruptive Innovation in Health Care Delivery: A Framework for Business-Model Innovation. Health Affairs (Project Hope) 27 (5): 1329-35. https://doi.org/10.1377/hlthaff.27.5.1329.

25. Khanna, Tarun, and Krishna G. Palepu. 1997. Why Focused Strategies May Be Wrong for Emerging Markets. Harvard Business Review 75: $41-51$.

26. Khanna, Tarun, Krishna G. Palepu, and Jayant Sinha. 2005. Strategies That Fit Emerging Markets. Harvard Business Review. https://hbr.org/2005/06/strategies-that-fit-emerging-markets.

27. Kolk, Ans, Miguel Rivera-Santos, and Carlos Rufín. 2014. Reviewing a Decade of Research on the 'Base/Bottom of the Pyramid' (BOP) Concept. Business \& Society 53 (3): 338-77. https://doi.org/10.1177/0007650312474928.

28. Kroll, Henning, and Madeleine Gabriel. 2020. Frugal Innovation in, by and for Europe. International Journal of Technology Management 83 (1-3): $34-54$. https://doi.org/10.1504/IJTM.2020.109230.

29. Leliveld, André, and Peter Knorringa. 2018. Frugal Innovation and Development Research. The European Journal of Development Research 30 (1): $1-16$. https://doi.org/10.1057/s41287-017-0121-4.

30. Liu, Yang, and Jiang Wei. 2018. Frugal Innovation in Resource-Constrained Emerging Markets. Academy of Management Proceedings 2018 (1): 11629. https://doi.org/10.5465/AMBPP.2018.11629abstract.

31. London, Ted, Ravi Anupindi, and Sateen Sheth. 2010. Creating Mutual Value: Lessons Learned from Ventures Serving Base of the Pyramid Producers. Journal of Business Research, Subsistence Marketplaces: Sustainable Consumption and Commerce For a Better World, 63 (6): $582-94$. https://doi.org/10.1016/j.jbusres.2009.04.025.

32. Luo, Yadong. 2003. Market-Seeking MNEs in an Emerging Market: How Parent-Subsidiary Links Shape Overseas Success. Journal of International Business Studies 34 (3): 290-309. https://doi.org/10.1057/palgrave.jibs.8400027.

33. Mair, Johanna, and Ignasi Marti. 2009. Entrepreneurship in and around Institutional Voids: A Case Study from Bangladesh. Journal of Business Venturing, Special Issue Ethics and Entrepreneurship, 24 (5): 419-35. https://doi.org/10.1016/j.jbusvent.2008.04.006.

34. Mair, Johanna, Ignasi Marti, and Marc J. Ventresca. 2012. Building Inclusive Markets in Rural Bangladesh: How Intermediaries Work Institutional Voids. Academy of Management Journal 55 (4): 819-50. https://doi.org/10.5465/amj.2010.0627.

35. Miles, Matthew B., A. Michael Huberman, and Johnny Saldana. 2013. Qualitative Data Analysis: A Methods Sourcebook. SAGE Publications.

36. Oliver, Christine. 1997. Sustainable Competitive Advantage: Combining Institutional and Resource-Based Views. Strategic Management Journal 18 (9): 697-713.

37. Onsongo, Elsie. 2017. Institutional Entrepreneurship and Social Innovation at the Base of the Pyramid: The Case of M-Pesa in Kenya. Industry and Innovation 0 (0): 1-22. https://doi.org/10.1080/13662716.2017.1409104.

38. Onsongo, Elsie, and Peter Knorringa. 2020. Comparing Frugality and Inclusion in Innovation for Development: Logic, Process and Outcome. Innovation and Development 0 (0): 1-21. https://doi.org/10.1080/2157930X.2020.1811931.

39. Peng, Mike W. 2003. Institutional Transitions and Strategic Choices. The Academy of Management Review 28 (2): $275-96$. https://doi.org/10.2307/30040713.

40. Pisoni, Alessia, Laura Michelin, and Gloria Martignoni. 2018. Frugal Approach to Innovation: State of the Art and Future Perspectives. Journal of Cleaner Production 171 (Supplement C): 107-26. https://doi.org/10.1016/j.jclepro.2017.09.248.

41. Pitelis, Christos N., and David J. Teece. 2010. Cross-Border Market Co-Creation, Dynamic Capabilities and the Entrepreneurial Theory of the Multinational Enterprise. Industrial and Corporate Change 19 (4): 1247-70. https://doi.org/10.1093/icc/dtq030.

42. Prahalad, C. K., and Allen Hammond. 2002. Serving the World's Poor, Profitably. Harvard Business Review 80: 48-57.

43. Radjou, Navi, Jaideep Prabhu, and Simone Ahuja. 2012. Jugaad Innovation: Think Frugal, Be Flexible, Generate Breakthrough Growth. John Wiley \& Sons.

44. Radjou, Navi, Jaideep Prabhu, and others. 2015. Frugal Innovation: How to Do More with Less. PublicAffairs.

45. Ramdorai, Aditi, and Cornelius Herstatt. 2015. Frugal Innovation in Healthcare: How Targeting Low-Income Markets Leads to Disruptive Innovation. 2015 edition. Switzerland: Springer.

Page $13 / 15$ 
46. Rao, Balkrishna C. 2013. How Disruptive Is Frugal? Technology in Society 35 (1): 65-73. https://doi.org/10.1016/j.techsoc.2013.03.003.

47. Sarasvathy, Saras D. 2001. Causation and Effectuation: Toward a Theoretical Shift from Economic Inevitability to Entrepreneurial Contingency. The Academy of Management Review 26 (2): 243-63. https://doi.org/10.2307/259121.

48. Scherer, Andreas Georg, Guido Palazzo, and David Seidl. 2013. Managing Legitimacy in Complex and Heterogeneous Environments: Sustainable Development in a Globalized World. Journal of Management Studies 50 (2): 259-84. https://doi.org/10.1111/joms.12014.

49. Schuster, Tassilo, and Dirk Holtbrügge. 2014. Resource Dependency, Innovative Strategies, and Firm Performance in BOP Markets. Journal of Product Innovation Management 31 (S1): 43-59. https://doi.org/10.1111/jpim.12191.

50. Sehgal, Vikas, Kevin Dehoff, and Ganesh Panneer. 2010. The Importance of Frugal Engineering. Strategy+business. 2010. http://www.strategybusiness.com/article/10201?gko=24674.

51. Sharma, Arun, and Gopalkrishnan R. Iyer. 2012. Resource-Constrained Product Development: Implications for Green Marketing and Green Supply Chains. Industrial Marketing Management, Green marketing and its impact on supply chain, 41 (4): 599-608. https://doi.org/10.1016/j.indmarman.2012.04.007.

52. Simanis, Erik, and Stuart L. Hart. 2009. Innovation From the Inside Out. MIT Sloan Management Review, Cambridge 50 (4): 77-86.

53. Soni, Pavan, and Rishikesha T. Krishnan. 2014. Frugal Innovation: Aligning Theory, Practice, and Public Policy. Journal of Indian Business Research 6 (1): 29-47. https://doi.org/10.1108/JIBR-03-2013-0025.

54. Strauss, Anselm, and Juliet Corbin. 1998. Basics of Qualitative Research: Techniques and Procedures for Developing Grounded Theory, 2nd Ed. Vol. xiii. Thousand Oaks, CA, US: Sage Publications, Inc.

55. Tiwari, Rajnish, and Cornelius Herstatt. 2012. Frugal Innovations for the 'Unserved' Customer: An Assessment of India's Attractiveness as a Lead Market for Cost-Effective Products. SSRN Scholarly Paper ID 2014614. Rochester, NY: Social Science Research Network.

https://papers.ssrn.com/abstract=2014614.

56. Tiwari, Rajnish, Katharina Kalogerakis, and Cornelius Herstatt. 2014. Frugal Innovation and Analogies: Some Propositions for Product Development in Emerging Economies. https://doi.org/10.15480/882.1173.

57. Tracy, Sarah J. 2020. Qualitative Research Methods: Collecting Evidence, Crafting Analysis, Communicating Impact. John Wiley \& Sons.

58. Winkler, Thomas, Anita Ulz, Wolfgang Knöbl, and Hans Lercher. 2019. Frugal Innovation in Developed Markets - Adaption of a Criteria-Based Evaluation Model. Journal of Innovation \& Knowledge, December. https://doi.org/10.1016/j.jik.2019.11.004.

59. Yin, Robert K. 2009. Case Study Research: Design and Methods. Sage Publications.

60. Zedtwitz, Max von, Simone Corsi, Peder Veng Søberg, and Romeo Frega. 2015. A Typology of Reverse Innovation. Journal of Product Innovation Management 32 (1): 12-28. https://doi.org/10.1111/jpim.12181.

61. Zeschky, Marco B., Bastian Widenmayer, and Oliver Gassmann. 2011. Frugal Innovation in Emerging Markets. Research-Technology Management 54 (4): 38-45. https://doi.org/10.5437/08956308X5404007.

62. Zeschky, Marco B., Stephan Winterhalter, and Oliver Gassmann. 2014. From Cost to Frugal and Reverse Innovation: Mapping the Field and Implications for Global Competitiveness. Research Technology Management 57 (4): 20-27.

\section{Figures}

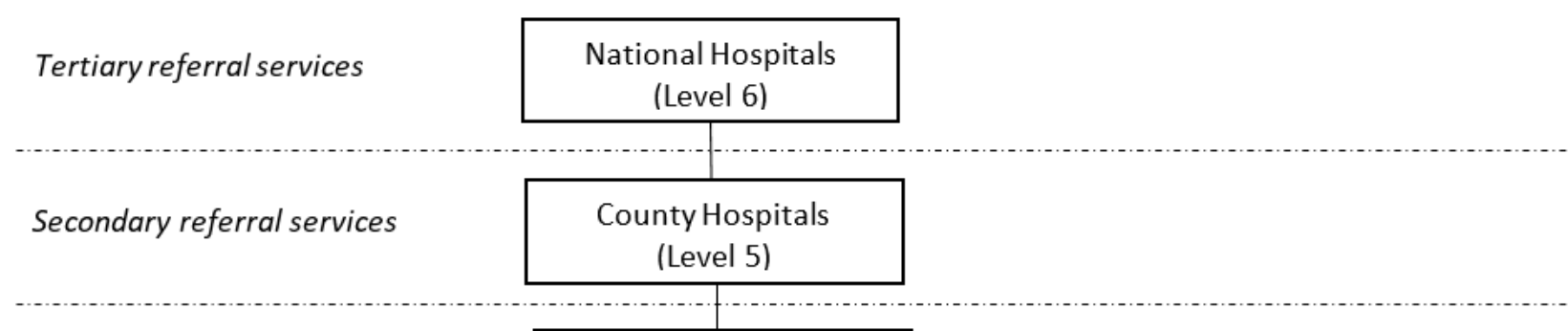

Primary care/referral services

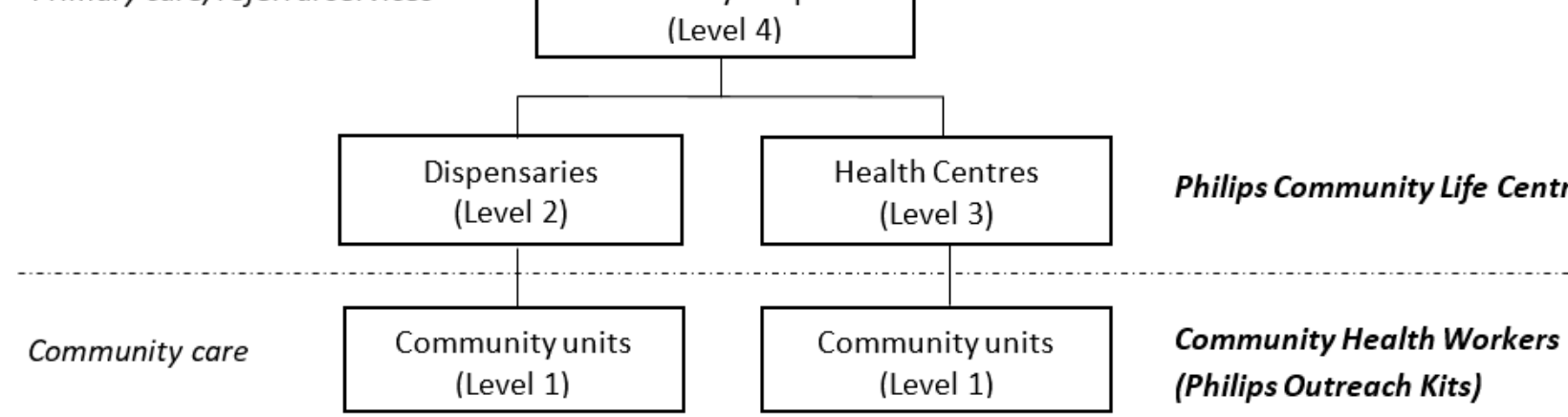

Figure 1 
Levels of healthcare delivery outlined in the Kenya Essential Package for Health (KEPH)

\section{Supplementary Files}

This is a list of supplementary files associated with this preprint. Click to download.

- Appendix1.docx 